\title{
Menslike subjekte in gemeente-opbou volgens die Kolossensebrief
}

\section{'n Diakoniologiese perspektief met toespitsing op eskatologiese dimensies}

\author{
V. Combrink en C.J.H. Venter \\ Dept. Diakoniologie \& Missiologie \\ Potchefstroomse Universiteit vir $\mathrm{CHO}$ \\ POTCHEFSTROOM
}

\begin{abstract}
Human subjects building up the congregation according to the epistle to the Colossians - a diaconiological perspective with special reference to eschatological dimensions

The basic issues dealt with in this article include the investigation of data in the epistle to the Colossians regarding human subjects in huilding up the congregation. In the analysis of material, special attention is given to the following aspects: the imperatives underlying the building up of the congregation, the use of building-up metaphors in this epistle, the role of the epistle itself as written by an apostle as a medium of edification. In the last instance, attention is paid to the function of human subjects in the process of building up the congregation. In the analysis the eschatological character of building up the congregation is dealt with. From the results of this investigation guidelines for practical application are given.
\end{abstract}

\section{Inleiding}

Gemeente-opbou sou omskryf kan word as die eskatologiese gebeure waardeur God Drie-enig as soewereine Subjek sy gemeente universeel en plaaslik opbou ekstensief (in getalle) en intensief (in geloof, hoop en liefde). Daar word gestel dat gemeente-opbou eskatologies van aard is op grond van die volgende: Eskatologie dui enersyds op die toekomstige, finale koms van die koninkryk en andersyds op die voorlopige (nog nie finale) dog (reeds) beslissende inbraak van die nuwe aeon van die toekoms in die oue met die koms van Christus en die Heilige Gees (Coetzee, 1984b:332). Gemeente-opbou is eskatologies van aard omdat dit plaasvind tussen die eerste en tweede fase van Christus se koms. In 
die opbou van sy gemeente maak God gebruik van menslike subjekte met die doel om die gelowiges diensbaar te maak aan sy koninkryk.

Die vraag na die funksie van die menslike subjekte in gemeente-opbou het die afgelope dekades in diakoniologiese besinning 'n sentrale belangstellingsveld geword (Weth, 1986:7; Te Velde, 1989:6). Die belangstelling het onder andere na vore gekom as 'n poging om weerstand te probeer bied teen die verderwende invloed van sekularisme op kerke (Noordegraaf, 1990:124).

Uit tersaaklike vakliteratuur blyk dit dat die funksie van menslike subjekte in die opbou van die gemeente wel in die algemeen ondersoek is - vergelyk byvoorbeeld die werke van Kuyper (1909), Kraemer (1958), Trimp (1978 \& 1982), Noordegraaf (1980), Te Velde (1992a \& 1992b) en Nel (1994) - maar daar is nog nie in diepte op die Kolossensebrief as ondersoekbron gefokus nie. Die Kolossensebrief bevat egter kardinale materiaal wat ontgin behoort te word.

Wat die betekenis van die eskatologie in die Kolossensebrief vir gemeenteopbou betref, sou 'n mens byvoorbeeld die volgende aspekte kon onderskei: die eskatologiese grond vir gemeente-opbou, die eskatologiese vertrekpunt, gemeente-opbou as eskatologiese gebeure in die tussentyd, die eskatologiese inhoud van gemeente-opbou (naamlik geloof, hoop en liefde) en die bedreiging vanuit die ou aeon as noodsaak vir gemeente-opbou (Combrink, 1993:27). 'n Dwarslyn wat die voorgenoemde aspekte sny, is die funksionele rol van die gelowiges as menslike subjekte in die eskatologiese opbougebeure, en dit is hierdie aspek wat vervolgens nader bespreek sal word.

As probleemstelling kan die vraag gestel word: Watter basisteoretiese gegewens kan vanuit die Kolossensebrief vasgestel word oor die instrumentele diens van die menslike subjekte in die eskatologiese opbou van die gemeente? Die navorsingshipotese is dat die Kolossensebrief stof bevat oor die plek en funksie van menslike subjekte in die opbou van die gemeente, en dat hierdie materiaal nader ondersoek en verdiskonteer behoort te word met die oog op gemeenteopbou in die praktyk.

Dié hipotese word nader ondersoek deur langs die weg van analise en interpretasie 'n neerslag van 'n eksegetiese verkenning te gee - nie 'n volledige eksegetiese ontleding nie - en daaruit sekere riglyne vir die praktyk van hedendaagse gemeente-opbou te distilleer.

\section{Neerslag van 'n eksegetiese verkenning}

Die eksegetiese bevindinge word soos volg aan die orde gestel:

2.1 Die kollektiewe karakter van die opbou-imperatiewe. 
2.2 Metafore wat die menslike subjekte van die opbou aandui.

2.3 Die instrumentele rol van die Kolossensebrief as apostoliese Skrifwoord in die opbou van die gemeente.

2.4 Die funksie van die menslike subjekte in die verloop van die gemeenteopbou.

\subsection{Die kollektiewe karakter van die opbou-imperatiewe}

Die drieluik indikatief-imperatief-belofte (Coetzee, 1984a:1 e.v.) kom in die Skrif binne 'n gemeenskapsraam voor. Dit wat God gee en eis en belowe, word gerig op die gemeente van die Ou sowel as die Nuwe Verbond. Waar die enkele gelowige die fokuspunt is, is hy steeds indiwidu-in-gemeenskap.

In die Kolossensebrief het die opbou-imperatiewe ook 'n onmiskenbare kollektiewe karakter. Die (uitdruklike of versweë) opbou-opdragte word aan die gemeente gegee, aan "almal in Kolosse wat aan God behoort, getroue broers in Christus" (1:2). Die gemeente se funksie as subjek in die gemeente-opbou as eskatologiese gebeure in die tussentyd word veral in twee kem-imperatiewe van die brief se hoofbetoog gegee: 2:6-7 en 3:1-4.

In 2:6-7 vind die oorgang plaas van die inleiding van die brief (1:1-2:5) na die hoofbetoog (2:6-4:6) (vgl. Du Toit, 1984:11). Die oorgang word aangedui deur o ̂े $v$ in 2:6 as konklusie op die inleiding van die brief (1:3-2:5). In 2:6 word die sentrale opbou-opdrag gegee om in verbondenheid met Christus as Here te lewe. Die beslissende heilsordelike erkenning van die heerskappy van die verhoogde Here oor die Kolossense is die eskatologiese vertrekpunt vir die opbou-eis om in 'n omvattende, eksklusiewe en voortdurende gemeenskap met Hom te volhard. Die gelowiges kan mekaar help (opbou) in hulle gemeenskap met die Here omdat hulle 'n eskatologiese bouwerk is (2:7) wat uiteindelik finaal voltooi sal word (Nel, 1987:53).

Die sentrale opbou-opdrag in 2:6-7 het twee implikasies wat ook in die vorm van imperatiewe gegee word - soos dit geformuleer word in 2:8-15 en 2:16-23.

Die eerste implikasie van die opdrag in 2:6-7, naamlik dat niemand die Kolossense van Christus Jesus, die Here wegvoer nie $(2: 8)$, is 'n gemeenskaplike roeping. Die onderlinge ondersteuning in die stryd teen die dwaalleer word geimpliseer. Die gelowiges moet hulle geledere sluit in hulle stryd teen die bedreiging vanuit die ou aeon, naamlik teen die bedreiging van die valse leer. Die valse leer staan engeleverering $(2: 9,15)$ voor, misken Christus se versoeningswerk (2:8) en poog om Christus te komplementeer (2:10). Die opdrag in 2:8 word gevolg deur 'n vierledige motivering wat telkens deur ŏ $\tau 1$ of 
'n geïmpliseerde ö $\tau$ ingelui word. In die vierledige motivering val die merkers

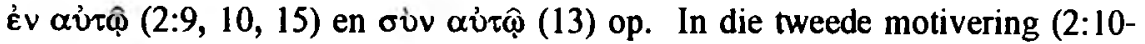
12) word die nadere bepaling van die Here Jesus Christus ingelui deur oั $\varsigma(10$, 11) en $\hat{\phi}(12)$. Al die herhalings verskerp die fokus op die opdrag om slegs aan die Here Jesus Christus vas te hou.

In die die perikoop 2:16-23 word die opdrag aan die gelowiges gegee om nie hulle lewens deur menslike voorskrifte te laat reguleer nie.

Ook die tweede implikasie van die opdrag in 2:6-7, naamlik die eis aan die gelowiges om nie hulle lewens deur menslike voorskrifte te laat reguleer nie (2:16-23), is 'n kollektiewe verantwoordelikheid. Die gelowiges word opgeroep om saam teen die bedreiging vanuit die ou aeon te stry, naamlik wettisisme (2:16), engeleverering (2:18) en die miskenning van Christus se soewereine heerskappy en sorg (2:19).

Die perikoop 3:1-4:6, wat deel is van die hoofbetoog van die brief, bied 'n konklusie op grond van 2:6-23 en word ingelui deur oû̃ $v$ in 3:1. Die tema van 3:1-4:6 word as 'n opbou-imperatief in 3:1-4 gestel, naamlik om as gelowiges gesamentlik na die dinge daarbo te strewe. Twee implikasies spruit voort uit die opdrag, ook in die vorm van imperatiewe. Die eerste imperatief is die opdrag in 3:5-11 om met die ou mens en sy gewoontes te breek en die tweede imperatief is die gebod in 3:12-4:6 om die lewe van die nuwe mens te leef. Die eskatologiese opbougebeure word deur die Seun as Kurios en Lewensbron (3:12) bepaal.

Die hoofbetoog van die Kolossensebrief, wat saamtrek in die twee sentrale opdragte: 2:6-7 en 3:1-4, word aan die gemeente as geheel gerig. Die gelowiges is gesamentlik verantwoordelik om uit die Here Jesus Christus te lewe. Indien hulle die opdragte uitvoer, word hulle as mense van die nuwe aeon opgebou tot geestelike volwassenheid.

\subsection{Metafore wat die menslike subjekte van die opbou aandui}

Bepaalde beeldspraak word in die Kolossensebrief gebruik waarmee die gemeente aangedui word as subjek van gemeente-opbou. Die volgende metafore word kortliks bespreek: liggaam, plant, gebou, volk.

\subsubsection{Liggaam}

Die gemeente word in 1:18 en 2:19 aangedui as 'n liggaam. In 1:18 word gestel dat die Seun die Hoof is van die liggaam, die kerk. Hierdie is die derde van vier nadere aanduidings van die Seun onder wie se heerskappy Paulus en Timoteus (en die ander gelowiges) gestel is. Die Seun, onder wie se heerskappy 
die gelowiges gestel is, is reeds as Verlosser van die gemeente (1:14) en Heerser van die skepping (1:15-17) getipeer en word nou in die derde plek (1:18) as Hoof van sy gemeente geteken.

In die uitdrukking Hoof van die liggaam is Hoof en liggaam nie 'n saamgestelde metafoor nie, maar twee beelde elk met 'n selfstandige betekenis (Ridderbos, 1971:425). Christus kan nie as 'n onderdeel van sy eie liggaam geag word nie (Roberts 1984:306). Hoof en liggaam kan nie vermeng word nie, maar ook nie van mekaar geskei word nie (Van der Walt, 1976:46-47).

In teenstelling met Romeine 12 en 1 Korintiërs 12 waar die hoof aangedui word as een van die organe van die liggaam wat as 'n eenheid saamwerk, word die klem in Kolossense en Efesiërs daarop geplaas dat Christus die eksklusiewe Hoof is wat die liggaam beheer en versorg (Du Plessis, 1978:22).

In Kolossense 1:18 is Christus as Hoof die bron van lewe en krag van die liggaam (Bruce, 1980:204). Hy lei en kontroleer die liggaam sodat dit doelmatig as 'n eenheid funksioneer (Carson, 1983:43). Die implikasie hiervan is dat die gelowiges saam deur die Hoof as soewereine Subjek van gemeenteopbon gelei word om as menslike subjekte mekaar organies te komplementeer in die eskatologiese opbou van die liggaam.

Ook in 2:19 word die gemeente as subjek van gemeente-opbou aangedui as 'n liggaam. In die gedagte-eenheid 2:16-23 kry die gelowiges 'n opdrag: hulle mag nie hulle lewens deur menslike voorskrifte laat reguleer nie. In 2:18-19 word hulle gewaarsku om nie op visioene en engele te vertrou nie, maar om aan Christus as hulle enigste ware Hoof vas te hou. Vers 19 is 'n nadere kwalifikasie van die Hoof en sy verhouding met sy gemeente. Teenoor die vleeslike godsdienstigheid waarop die vals leraars vertrou, word Christus hier aangedui as die ware en onmiddellike Bron van die gemeente se groei (Bratcher \& Nida, 1977:69). As eskatologiese gebeure word die groei primêr intensief, nıaar ook ekstensief voltrek (Delling, 1972:518; Schweizer \& Baumgärtel, 1971:1076). Christus se hoofskap kwalifiseer Hom voorts as die Goddelike Subjek van die opbou. Hy maak dit moontlik dat sy liggaam groei deurdat die gelowiges as 'n eenheid saamgevoeg word en elke lid sy funksie vervul (Louw \& Nida, 1988:127; Hendriks, 1992:73). Die gewrigte en spiere kan of dui op die diens van die gelowiges of dié van die apostel óf sy medewerkers (1:7-9; 1:23-2:1) (Schweizer, 1982:164; Van der Walt, 1976:62). Die eskatologiese groei word angedui deur die praesenstyd van die deelwoorde

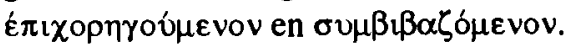

Die onderlinge verbondenheid wat met die metafoor liggaam van Christus aangedui word, kom ook sterk na vore in Romeine 12:4-5, 1 Korintiërs 12 en 
Efesiërs 4 (Roberts, 1984:306-309). In Efesiërs 4:16 dra die onderlinge opbou deur die gelowiges 'n organiese karakter " ... het lichaam, dat als een welsluitend geheel en bijeengehouden door de dienst van al zijn geledingen aan Christus zijn wasdom ontleent om zichzelf op te bouwen in de liefde" (Ridderbos, 1971:422).

In die verloop van die eskatologiese groei voltrek God sy plan en gebruik Hy die gelowiges as die menslike subjekte van gemeente-opbou: hulle ondersteun mekaar in hulle geloof in Christus, hulle Hoof.

\subsubsection{Plant}

Die gemeente as menslike subjek van gemeente-opbou word ook aangedui met die beeld van 'n plant. In 2:6 word die gelowiges beveel om in verbondenheid met Christus Jesus, die Here te lewe. Die grond vir die opdrag word deur vers 7 a aangedui.

Die eerste grond vir die opdrag om in verbondenheid met Christus te lewe, is die feit dat die Kolossense reeds permanent in Hom gewortel is (vgl. die perfektumtyd: $\dot{\varepsilon} \rho p(\zeta \omega \mu \varepsilon v o l)$. Die band word met Christus gelê deur die lewewekkende, wederbarende werk van die Heilige Gees. Die implikasie hiervan is dat die gemeente steeds uit Christus lewe soos wat 'n plant uit sy groeibodem lewe. So word die gemeente (as plant) voortdurend deur die Heilige Gees opgebou (gevoed) in hulle geloof in Christus. Die plant-metafoor beklemtoon dat die opbou organies geskied. Die gemeente word inderdaad geplant deur die Heilige Gees wat menslike instrumente gebruik (vgl. in hierdie verband bv. 1 Kor. $3: 6$; Ef. $3: 17 ; 4: 15-16$ ). Die gelowiges is nie net objek van die eskatologiese opbou nie, maar ook subjek deurdat hulle op organiese wyse onderling van mekaar afhanklik is vir hulle opbou in die geloof.

\subsubsection{Gebou}

Die gebou is die volgende metafoor wat die gemeente as subjek van gemeenteopbou tipeer. Die opdrag in 2:6 om in verbondenheid met Christus te lewe, word in 2:7a begrond.

Die opbou geskied deurdat die Heilige Gees die gelowiges soos stene op die Here Christus as fondament opbou. Uiteraard het die opbou 'n kontinue karakter wat aangedui word deur die praesenstyd van die passiewe deelwoord:

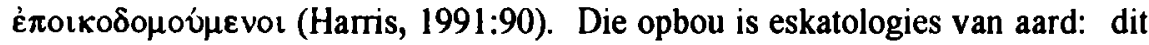
word nie in hierdie bedeling volvoer nie, maar gaan voort totdat die einddoel bereik is (Ridderbos, 1971:479). 
Die opbou van die gemeente (as bouwerk) is openbaringshistories gebaseer op die profetiese belofte van die herstel en heropbou van die volk Israel na die ballingskap (Nel, 1994:3). In die plek van die Ou-Testamentiese tempel en erediens kom die gemeente as geestelike huis wat as lewende stene opgebou word (vgl. in hierdie verband ook Skrifgedeeltes soos bv. Rom. 15:20, 1 Kor. 3:9-11, 16-17, 4:1, 2 Kor. 6:16, Gal. 6:10, Ef. 2:19-22, 3:2, 1 Tim. 1:4, 3:15, Tit. 1:7, 1 Pet. 2:5). Die opbou van die gemeente is intensief-bewarend (Kol. $1: 9-12,28-29 ; 2: 1-4: 6)$ sowel as ekstensief-vermeerderend $(1: 6-8,13,21-23$; $2: 6 ; 3: 11 ; 4: 5)$.

Die boumetafoor (die gemeente as bouwerk met sy lewende stene wat mekaar ondersteun) karakteriseer gelowiges onmiskenbaar as menslike subjekte van die eskatologiese opbougebeure.

\subsubsection{Volk}

Die volgende beeld waarmee die gemeente as subjek van gemeente-opbou getipeer word, is dié van 'n volk. Kolossense 3:12a, wat hier van toepassing is, is die indikatiewe motivering van die opdrag (12b) om die eienskappe van die nuwe mens te vertoon. God het die gelowiges uit die ou aeon uitverkies (Ladd, 1975:474, 480).

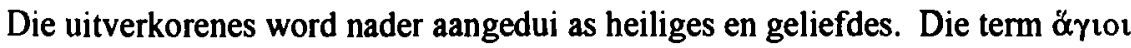
het 'n eskatologiese betekenis: Christus het sondaarmense reeds vir God en sy diens afgesonder. Die gelowiges in Kolosse leef in die bedeling waarin die ou en nuwe aeon mekaar oorvleuel (Coetzee, 1984b:350). Die kerk is 'n eskatologiese gemeenskap wat vreemd is aan hierdie bedeling (Ladd, 1976:339).

Die lede van die uitverkore volk is organies aan mekaar verbonde en het as menslike subjekte die roeping om mekaar op te bou om as nuwe mense in 'n ou wêreld te leef.

\subsection{Die instrumentele rol van die Kolossensebrief as apostoliese Skrifwoord in die opbou van die gemeente}

God die Heilige Gees as Subjek gebruik mense as subjekte om sy Woord op Skrif te stel en verseker daarmee die opbou van die gemeente.

In die briefaanhef (1:1-2) dui die apostel Paulus homself aan as die afsender van die brief. Die brief kan gedateer word as ongeveer 60-61 n.C. toe Paulus twee jaar lank in die gevangenis sy verhoor voor die keiser afgewag het (Hand. 28:30, Fil. 1:13, 4:22) (Coetzee, 1975:75-76). Omdat die apostel nie by die gelowiges teenwoordig kan wees om raad en leiding te gee nie (2:5), skryf hy 
aan hulle. Sy brief dien as 'n wyse van teenwoordigstelling ( $\pi \alpha \rho o v \sigma i ́ \alpha)$ (vgl. 1 Kor. 5:3).

Op hierdie wyse word die apostel as openbaringsorgaan deur die Heilige Gees, die Goddelike Outeur, gebruik (Greijdanus, 1946:45-46). As Subjek verseker die Heilige Gees die opbou van die gelowiges deur die brief as gesagvolle apostoliese Skrifwoord (Ridderbos, 1955:39, 57-58; Du Toit, 1977:117, 120, 149). Christus kom deur die apostel aan die Woord (vgl. byvoorbeeld Luk. 10:16 en Mark. 3:15) en daarmee word die brief as kanoniek gestempel (Guthrie, 1970:388).

Die brief kan voorts as 'n geleenthieidsgeskrif, as ad hoc-korrespondensie bestempel word, as gemeente-opbou by uitnemendheid (Du Toit, 1984:2; Floor, 1982:2). Die brief is ' $n$ skakel in die ketting van gemeente-opbou aangesien dit een bepaalde inset uitmaak van die opbou wat gestruktureer is binne die raamwerk van God se soewereiniteit en die mens se verantwoordelikheid. Die opbou van die gemeente in Kolosse verloop planmatig (vgl. Combrink, 1993:269-272). Ook uit ander Skrifgedeeltes is dit duidelik dat Christus na sy hemelvaart sy gemeente op aarde deur die gesagvolle skriftelike getuienis van sy apostels opbou (1 Tess. 5:27; 2 Tess. 3:14-15) (Coetzee, 1973:76-82).

Gemeente-opbou geskied in die Nuwe-Testamentiese briewe by wyse van pastorale sorg (Du Toit, 1984:2). Die Kolossensebrief is kanonieke tyd- en situasiegerigte prediking/pastoraat waardeur die Heilige Gees die opbou van die geaddresseerdes destyds (en vandag) bewerkstellig.

Naas die Skrifwoord gebruik die Heilige Gees ook die verkondiging van die Woord deur menshike subjekte om die gemeente op te bou. Die skriftelike en mondelinge Woordbediening aan die Kolossense sluit by mekaar aan en daar is geen spanning tussen die twee gestaltes van die Woord nie (vgl. Adams, $1981: 22,24)$.

\subsection{Die funksie van menslike subjekte in die verloop van die gemeente-opbou}

In die verloop van die gemeente-opbou maak God instrumenteel gebruik van Paulus, Epafras, Tigikus, Markus, Timoteus en ander gelowiges.

\subsubsection{Paulus as subjek in die opbougebeure}

Paulus se apostoliese diens in die opbou van die gemeente blyk onder andere uit $1: 1$ a, $4 ; 1: 29-2: 2$ en $4: 2-4$. 
In die bespreking van 1:1a in punt 2.3 is reeds verwys na die rol van die apostel as menslike subjek in die totstandkoming van die Skrifwoord. Dit is egter belangrik om ook daarop te let dat die apostel se bediening in sy geheel deur die Heilige Gees gebruik word om die gemeente op te bou. Christus verrig sy volmagswerk na sy hemelvaart deur die geroepe en deur die Gees toegenuste apostolaat.

In 1:4 val dit op dat die apostel Paulus al sy insette in die opbou van die gemeente volledig diensbaar maak aan God se doel, plan, versorging, leiding en voorskrifte vir sy kerk.

Die opbouwerk van die apostel is volgens 1:29 'n volgehoue, inspannende en vermoeiende taak (Hauck, 1972:829), en sluit onder andere die volgende aspekte in: selfverloëning, gebed, luister na God, noukeurige beplanning, korrespondensie, koers aandui, aanval en verdedig (Hendriksen, 1974:94). Die apostel se toegewyde bediening word moontlik gemaak deur die kragtige werking van die Gees van die opgestane Here (Grundmann, 1971:310).

Die apostel se konstante liefde en besorgdheid en die bekendmaking daarvan aan die Kolossense (2:1-2) bou hulle op in hulle liefdesgemeenskap met mekaar en met Christus. As mense van die nuwe aeon kan die gelowiges liefde betoon want hulle lewe tussen die knuis en die wederkoms (Quell \& Stauffer, 1969:51).

Volgens 4:2-4 maak God die ekstensiewe opbou van sy gemeente moontlik deurdat $\mathrm{Hy}$ geleenthede skep vir die verkondiging van die Woord deur die apostel en dit ook ingang laat vind by mense (Ridderbos, 1960:234). Deur middel van die verkondiging van die apostel openbaar Christus Homself as die geheimenis en verseker Hy dat ook nie-Jode in sy genade mag deel (1:26-27) (Müller, 1958:161). Die apostel Paulus se prediking is deel van die eskatologiese gebeure (Ridderbos, 1971:44; Pop, 1987:187).

Uit die voorafgaande het dit duidelik geword dat God die primêre Subjek is wat Paulus se bediening gebruik. Die apostel se funksie in die eskatologiese opbou van die kerk word bevestig deur ander Skrifgedeeltes (vgl. byvoorbeeld 2 Kor. 4:14; Ef. 5:27; Fil. 2:16 en 1 Tess. 2:19).

\subsubsection{Epafras as subjek van die opbou}

In 1:5-7 word gestel dat die Kolossense van die verheerlikte en komende Christus gehoor het deur middel van die Woord wat Epafras aan hulle gebring het. Die bekendmaking van die hoop dra die karakter van gesagvolle aanvangsprediking (4:12-13) en lei tot 'n besliste wending: die gemeente kry deel aan die nuwe bedeling (Friedrich, 1971:719, 730). Die Woord bring vrug voort in die gemeente $(1: 4,7)$. Tydens Paulus se gevangenskap (waarskynlik in Rome 
ongeveer 59-61 n.C.) gee Epafras terugvoer oor die Kolossense se geloof en liefde $(1: 4,8 ; 4: 12)$. Epafras se verslag vorm 'n belangrike skakel in die kommunikasie van die evangelie en sy diens as leraar in die algemeen is noodsaaklik vir die eskatologiese opbou van die gemeente.

\subsubsection{Tigikus as subjek van die opbou}

Volgens 4:7-8 word Tigikus as draer van die brief na die gelowiges in Kolosse, Laodisea en Hiërapolis gestuur. Sy taak is om vas te stel hoe dit met hulle gaan, die brief aan hulle toe te lig en hulle te vertroos. Hulle kommer sal verlig word en hulle vrees verwyder word as hulle hoor dat die apostel se lyding nie die voortgang van die evangelie verhinder nie (vgl. ook Fil. 1:12-14). As briefdraer, -toeligter en parakleet is Tigikus 'n noodsaaklike skakel in die opbouketting.

\subsubsection{Markus as subjek van die opbou}

Volgens 4:10 was Markus ('n bekeerde Jood) goed op hoogte met die Kolossense se situasie en as sodanig was hy besonder geskik om diensbaar te wees aan die verdere verloop van hulle opbou.

\subsubsection{Timoteus as subjek in die opbouproses}

Timoteus word kortliks in 1:1a vermeld. In die opbou van die gemeente tree hy op as medewerker, (moontlike) amanuensis en mede-afsender (Martin, 1975:23).

\subsubsection{Die diens van die gelowiges in die opbou van die gemeente}

Naas die diens van die voorgenoemde werkers gebruik God ook die gelowiges in Kolosse om sy gemeente op te bou. Die diens van die gelowiges het reeds implisiet aan die orde gekom in punte 2.1 en 2.2 en word nou meer eksplisiet bespreek volgens $2: 2,2: 19,3: 16$ en $4: 17$.

In 2:2 stel die apostel die doel waarom hy sy ywer aan die gelowiges bekend maak, naamlik dat hulle daardeur aangespoor sal word om mekaar op te bou in hulle gemeenskap met Christus. Die doel van die gelowiges se liefdesgemeenskap met mekaar is om hulle volledige insig te gee in die rykdom van Christus. Die broederliefde word moontlik gemaak deur die nuwe aeon wat aangebreek het met Christus se koms. In hulle liefde breek die krag van die toekomstige eeu reeds deur in hierdie ou bedeling (Quell \& Stauffer, 1969:51). Die gelowiges word opgebou in hulle kennis van Christus in die konteks van die gemeenskap van die heiliges (Carson, 1983:56). 
Ook in 2:19 is die onderlinge verbondenheid van die gelowiges ter sprake, en hier word dit aangedui met die metafoor liggaam van Christus (Roberts, 1984:306-309). Liggaamsgroei geskied waar die gelowiges as eenheid saanigevoeg is en elkeen sy eie unieke funksie vervul (Louw \& Nida, 1988:127). Ook uit die apostel se brief aan die Efesiërs blyk dat die lede van die liggaam as ' $n$ lewende organisme betrek word in 'n voortdurende proses van onderlinge ondersteuning, voeding en liefdesbetoon (Ridderbos, 1971:422; Bratcher \& Nida, 1977:69).

Vervolgens word die rol van die gelowiges in die onderlinge opbou in $3: 16$ aangetoon. Die inhoud van die opbou-opdrag om die lewe van die nuwe mens te leef, is hier om as gelowiges die Woord van God aan mekaar te bedien. Die praesenstyd van die drie deelwoorde dui aan dat die nuwe lewe inderdaad nie staties is nie, maar tot uitdrukking kom as die dinamiese gemeenskap met medegelowiges.

Ook in 4:17 as deel van die slot van die brief word die gelowiges se opboutaak uitgespel: hulle is verantwoordelik vir die opbou van Argippus. Hulle moet naamlik 'n appèl op hom maak om sy bediening voort te sit en te voltooi te midde van die bedreiging van die dwaalleraars.

Uit die slot van die brief as geheel blyk dit verder dat die opbou van die gelowiges voltrek word deur middel van onderlinge meelewing en interaksie by wyse van korrespondensie, die voorlees van briewe, gesprek, gebed en die dra van mekaar se laste. Gemeenskap vind plaas tussen die apostel (en medewerkers) en die gemeente, tussen een gemeente en 'n ander en tussen gelowiges wat in 'n huis saamkom. Daar is telkens sprake van medegevangenes, medestryders en medewerkers.

Uit bogenoemde is dit duidelik dat die gemeenskap van die gelowiges 'n besondere funksie vervul in die eskatologiese opbou van die gemeente deurdat die lede van die liggaam in 'n proses van interaksie die Woord aan mekaar bedien en vir mekaar sorgdra.

Uit die eksegese van Kolossense (punt 2.4) is bevind dat God in die eskatologiese opbougebeure instrumenteel gebruik maak van medewerkers wat bepaalde dienste in die gemeente verrig. Die opbou geskied deur die diens van die gelowiges sowel as die dienste (ampte) van byvoorbeeld leraars, herders en evangeliste. Die ampte het 'n toerustende funksie ten opsigte van die gelowiges. 


\section{Riglyne vir die praktyk van gemeente-opbou}

Die bevindinge uit die eksegetiese verkenning ten opsigte van die instrumentele funksie van die menslike subjekte in gemeente-opbou is behandel ten opsigte van die volgende:

* Die kollektiewe karakter van die sentrale opbou-imperatiewe.

* Beeldspraak wat die menslike subjekte van die opbou aandui.

* Die funksie van die apostoliese Skrifwoord in die opbou.

* Die diens van die gelowiges en die ampte in die opbou.

Daar is veral bevind dat daar 'n verweefdheid is tussen die diens van die gelowiges en die ampte in die opbou van die gemeente. Hierdie bevinding vanuit die eksegese word nou verwerk in riglyne vir die praktyk van gemeenteopbou. Daar word gekonsentreer op die onderskeid in en samehang van die diens van die gelowiges en die ampte in gemeente-opbou. Die motivering hiervoor is dat die ander drie aspekte reeds in laasgenoemde aspek geïmpliseer word. Daar sal telkens verwys word na toepaslike resente literatuur wat erkenning gee aan die basisteoretiese bevinding dat God menslike subjekte in die eskatologiese opbougebeure gebruik.

\subsection{Die funksie van die ampte as subjekte van gemeente- opbou}

Uit die Kolossensebrief is vasgestel dat God in die opbou van sy gemeente instrumenteel gebruik maak van menslike instrumente wat bepaalde ampte beklee het: die apostel Paulus, die leraar Epafras, die herder Tigikus en medewerkers soos Markus en Timoteus.

Die ampte kan omskryf word as bedieninge wat Christus in die gemeente gegee het (bv. lering, vertroosting, vermaning, barmhartigheid) waardeur Hy met sy Woord en Gees die gelowiges roep, vergader en bou (Spoelstra, 1986:11; 1989:28).

Die dienste van ouderling (predikant) en diaken het basies 'n toerustende, leidinggewende en saambindende funksie ten opsigte van die diens van die gelowige (Te Velde, 1992b:97; Velema, 1992:19; Nel, 1994:56).

Al die gawes wat deur die dienste tot uitdrukking kom, moet gebruik word sodat die gemeente homself kan opbou (Van Roon, 1984:291; Richards, 1981:80-83, 98). 


\subsection{Die diens van die gelowiges as subjekte van gemeente- opbou}

Uit die analise van die Kolossensebrief het dit ook geblyk dat God die gemeenskap van die gelowiges gebruik in die opbou van sy gemeente. Die gelowiges dra naamlik sorg vir mekaar as lede van een liggaam.

Vandag het die mondigheid van die gemeente so op die voorgrond gekom dat daar selfs gepraat word van ' $n$ tweede hervorming. Die eerste hervorming het die Skrifwoord in die hande van die gelowiges teruggeplaas. Die tweede wil die dienswerk in hulle hande plaas (Heyns \& Pieterse, 1990:2). Dit was veral Kraemer wat stukrag aan die tweede hervorming gegee het (vgl. Fenhagen, 1977:23).

Deur middel van onderlinge bediening (Van der Walt, 1979:20), oftewel korporatiewe dienswerk (De Klerk, 1978:9), bou die gelowiges mekaar op (Richards, 1981:81; Venter, 1988:10-11,20).

\subsection{Die verhouding amp-gemeente}

Uit die Kolossensebrief het dit duidelik geword dat 'n hegte band en samewerking tussen die toerustende dienste en die diens van die gelowiges bestaan. Die insette van byvoorbeeld die apostel, leraars, herders en evangeliste help die gelowiges om hulle roeping as gemeente in die wêreld te vervul.

Die toerustende dienste is primêr gegee met die doel dat elke gelowige en die gelowiges saam in diens van God sal staan (Spoelstra, 1976:43; Hendriks, 1991:71-74; Te Velde, 1992b:108). Die dienste funksioneer primêr toerustend en nie namens of in die plek van die gelowiges nie (Nel, 1982:45; 1994:54, 55; Noordegraaf, 1990:141). Die dienste staan in die gemeente omdat amp en gemeente 'n eenheid vorm (Te Velde, 1989:30).

Die subjek-objek-verhouding, waarin die diens van die predikant meermale oorspan word (Louw, 1985:28), moet plekmaak vir 'n subjek-subjek-verhouding wat die mondigheid van die gemeente respekteer (Nel, 1988:12-13). Die oorspanning van die ampte is afgodery en daarom moet die pastorale kerkmodel gepaar word met die laïkale of kommunikatiewe model (Noordegraaf, 1990:134; Bons-Storm, 1987:110-112). In die opbou van die gemeente is daar 'n gesonde balans nodig: nóg die besondere dienste, nóg die diens van die ander gelowiges mag verabsoluteer of verkleineer word (Nel, 1994:5, 7, 55).

Die korrekte klem op sowel amp as diens van die gelowiges is nie gebore uit 'n wêreldse sug na demokratisering nie, maar is gefundeer op 'n reformatoriese ampsbeskouing wat afwysend staan teenoor hiërargisme sowel as kongregasio- 
nalisme (Noordegraaf, 1990:136-137). Die sogenaamde instituut- en verkondigingsmodelle fokus te sterk op die ampte, terwyl die liggaams- en transformasiemodelle die pendulum laat oorhel na die diens van die gelowiges (Hendriks, 1992:14-35).

Gemeenteleiers moet die diensknegfunksie van toerusters vervul (Nel, 1994:71 e.v.). Leierskap moet begeleidend van aard wees: dit gaan in leierskap primêr om die verstaan en stuur van gebeure wat die geloofsgemeenskap en dienswerk van 'n gemeente op 'n gedeelde toekomsvisie kan rig. Begeleidende leierskap verdiskonteer die volgende vier sake: presensie, visionering, fasilitering en energering (Smit, 1995:12 e.v.).

\subsection{Sterker klem op die diens van die gelowiges vandag}

Uit die Kolossensebrief het dit reeds duidelik geword dat die gelowiges mekaar destyds ondersteun het om eietydse bedreiginge die hoof te bied. Die aard van die leefwêreld van modeme gelowiges maak dit eweneens noodsaaklik dat daar in die praktyk van gemeente-opbou besondere aandag gegee sal word aan die gemeenskap van die gelowiges. Moderne gelowiges leef oorwegend in 'n verstedelikte omgewing met gepaardgaande verskynsels soos massafikasie, indiwidualisme en eensaamheid. Dié aspekte maak ' $n$ bedieningspraktyk noodsaaklik wat baie sterk op verhoudings gefokus is en waarin die diens en gawes van die gelowiges baie beter gebruik behoort te word (Hendriks, 1992:91, 93). Die dienswerk van die gelowiges is koinoniaal, pastoraal en charismaties van aard ( $\mathrm{Nel}, 1994: 40-46,227)$.

Bedieningstrukture wat koinonia moontlik maak, behoort geskep te word, byvoorbeeld die sel-in-die-liggaam-model (Louw, 1980:153), oftewel die dialogies-intensionele sisteemmodel wat ruimte skep vir die beplande en effektiewe kommunikasie van die evangelie deur koinonia en diakonia (Louw, 1985:36-39). Met die oog op bedieningstrukture wat koinonia moontlik maak, ontwerp Hendriks (1992:91-117) 'n praktykteorie van aanvullende koinoniaverbande waarin die gemeenskap van die gelowiges met die Drie-enige God en met mekaar in die huwelik, gesin, kleingroep, grootgroep, erediens en ander samekomste, asook die koninkryksgerigtheid en getuienis in die wêreld tot hulle reg kom.

Die dienswerk van die ampte en die ander gelowiges is interafhanklik en komplementerend; daarom behoort daar onder andere ruimte geskep te word vir die volgende:

* Strategiese beplanning en besluitneming deur 'n kerkraad in oorleg en gesprek met die gemeente. 
* Deelname van gelowiges aan die erediens en ander samekomste deur byvoorbeeld gebed, Skriflesing, lering, profesie, getuienis en sang.

* Deelname van gelowiges by diensgroepe op die terrein van bv. pastoraat, jeugsorg, barmhartigheid en evangelisering.

* Deelname van gelowiges aan belangegroepe.

* Deelname van gelowiges aan Bybelstudie-omgeegroepe.

\subsection{Mondige gelowiges se omgang met die Skrifwoord}

Uit die Kolossensebrief is vasgestel dat die voorgangers sowel as die gelowiges die Woord bedien het. Daar kan ook vandag van gelowiges verwag word om intensief aan die Skrifwoord blootgestel te word by wyse van verantwoorde Skriflesing, -ondersoek en -verklaring. Hierdie blootstelling aan die Skrif kan geskied deur byvoorbeeld sistematiese Bybellees tuis met of sonder verklarende literatuur, die benutting van tersaaklike radio- en televisieprogramme, klanken videokassette, ensovoorts.

\subsection{Bediening van die Woord deur gelowiges}

Uit die Kolossensebrief is dit opvallend dat die gelowiges destyds die Woord aan mekaar bedien het. Ook vandag is dit noodsaaklik dat gelowiges doelbewus daarna sal streef om al hulle geestesgawes - byvoorbeeld kennis, wysheid, profesie, lering en onderskeiding - in aksie te stel, sodat hulle die Woord ten volle aan mekaar sal bedien.

Die regte geleenthede moet geskep word vir Woordbediening, byvoorbeeld huisgodsdiens, katkisasie, groepsbybelstudie, erediensvoorbereiding, eredienste, preekbespreking, huisbesoek, opboukursusse, ensovoorts. Uiteraard behoort hierdie geleenthede gesinkroniseer te word met die gemeentelike visie en die toepaslike opboudoelwitte wat daaruit voortspruit.

Daar moet gewaak word teen 'n eensydige bediening wat die Woordverkondiging deur die prediking verabsoluteer ten koste van ander bedieningswyses. Daar bestaan 'n tradisionele opvatting dat indien die prediking maar net op peil is en daarmee saam die huisbesoek deur die predikant, ouderlinge en diakens, dan sal die gemeente as geloofsgemeenskap vanself reg funksioneer. Die praktyk bewys dat 'n gemeente ten spyte van goeie prediking nog steeds ver tekort kan skiet ten opsigte van koinonia en diens (Burger, 1991:21).

\section{Gevolgtrekking}

As probleemstelling is aanvanklik gevra: Watter instrumentele funksie vervul die gelowiges as menslike subjekte in gemeente-opbou as eskatologiese gebeure volgens die Kolossensebrief? 
Nadat die probleemstelling by wyse van eksegese en hermeneuse getoets is, kan die volgende gevolgtrekking gemaak word: God Drie-enig bou sy gemeente in die tussentyd (tussen hemelvaart en wederkoms) inderdaad op met sy Woord en Gees deur middel van menslike subjekte. Uit die ondersoek het dit veral aan die lig gekom dat die sentrale opbou-imperatiewe van die Kolossensebrief die gemeente as geheel tipeer as subjek van die opbou. Daar is ook bevind dat bepaalde beeldspraak die gemeente as subjek van die opbou impliseer. Die Skrifwoord stempel die apostel as instrumentele subjek van die opbou. Ten slotte is bevind dat binne die gemeente die diens van die gelowiges asook die bediening van die ampte in interafhanklikheid van mekaar deur God gebruik word in die eskatologiese opbou van sy gemeente.

Wanneer bogenoemde bevindinge op die praktyk van gemeente-opbou toegespits word, bied dit toepaslike riglyne vir 'n bedieningspraktyk waar die ampte so behoort te funksioneer dat die diens van die gelowiges tot sy reg sal kom.

\section{Bibliografie}

ADAMS, J.E. 1981. Competent to Counsel. 15th print. Grand Rapids : Baker.

BONS-STORM, R. 1987. Geloofwaardig: stappen op de weg van gemeenteopbouw. 's-Gravenhage : Boekencentrum. (Praktisch Theologische Handboeken, no. 54.)

BRATCHER, R.G. \& NIDA, E. 1977. A Translators Handbook on Paul's Letters to the Colossians and to Philemon. New York : United Bible Societies.

BRUCE, F.F. 1980. Commentary on the Epistle to the Colossians: The English Text with Introduction, Exposition and Notes. 11th print. Grand Rapids : Eerdmans.

BURGER, C. 1991. Die dinamika van 'n Christelike geloofsgemeenskap: nuut gedink oor gemeentes. Kaapstad : Lux Verbi.

CARSON, H.M. 1983. The Epistles of Paul to the Colossians and Philemon: an Introduction and Commentary. Grand Rapids : Eerdmans.

COETZEE, J.C. 1973. Kanon van die Ou en Nuwe Testament. Potchefstroom : PU vir CHO. (Diktaat.)

COETZEE, J.C. 1975. Die blye boodskap: 'n gids deur die boeke van die Nuwe Testament. Potchefstroom : Pro Rege.

COETZEE, J.C. 1984a. Drie wesentlike elemente van egte prediking: indikatief, imperatief en belofte. Potchefstroom : PU vir CHO. (Diktaat.) 
COETZEE, J.C. 1984b. Paulus se eskatologiese prediking. (In Du Toit, A.B., red. Handleiding by die Nuwe Testament. Band V. Die Pauliniese Briewe: Inleiding en teologie. Pretoria : NG Kerkboekhandel. p. 332364.)

COMBRINK, V. 1993. Die betekenis van die eskatologie in die Kolossensebrief vir gemeente-opbou: 'n diakoniologiese ondersoek. Potchefstroom : PU vir CHO. (Proefskrif - Th.D.)

DE KLERK, J.J. 1978. Herderkunde. Pretoria : NG Kerkboekhandel.

DELLING, G. 1972. $v \pi \varepsilon \rho \alpha v \xi \alpha v \omega, \alpha \dot{v} \xi \alpha v \omega$. (In Kittel, G., red. Theological Dictionary of the New Testament. Volume VIII. Grand Rapids : Eerdmans. p. 517-519.)

DU PLESSIS, 1.J. 1978. Die brief aan die Kolossense. Kaapstad : NG Kerkuitgewers.

DU TOIT, A.B. 1977. Prinsipiële gedeelte: die Nuwe Testament as kanon. (In Du Toit, A.B., red. Handleiding by die Nuwe Testament. Band I. Afdelings A: Inleiding tot die studie van die Nuwe Testament. Afdeling B: Kanoniek van die Nuwe Testament. Pretoria : NG Kerkboekhandel. p. 102-192.)

DU TOIT, A.B. 1984. Oriënterende opmerkings oor die Pauliniese briefliteratuur. (In Du Toit, A.B., red. Handleiding by die Nuwe Testament. Band V. Die Pauliniese Briewe: Inleiding en teologie. Pretoria : NG Kerkboekhandel. p. 1-22.)

FENHAGEN, J.C. 1977. Mutual Ministry. New York : Seabury.

FLOOR, L. 1982. Perspektiewe op die prediking van Paulus. Pretoria : NG Kerkboekhandel.

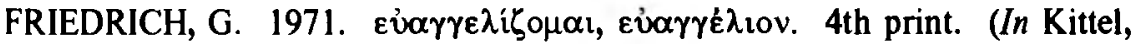
G., ed. Theological Dictionary of the New Testament. Volume II. Grand Rapids : Eerdmans. p. 707-736.)

GREIJDANUS, S. 1946. Schriftbeginselen ter Schriftverklaring en historisch overzicht over theorien en wijzen van Schriftuitleggen. Kampen : Kok.

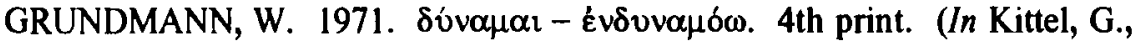
ed. Theological Dictionary of the New Testament. Volume II. Grand Rapids : Eerdmans. p. 284-317.)

GUTHRIE, D. 1970. New Testament Introduction. 3rd Edition. London : Tyndale.

HARRIS, M.J. 1991. Colossians \& Philemon. Grand Rapids : Eerdmans. HAUCK, F. 1972. кó Theological Dictionary of the New Testament. Volume III. p. 827-830.)

HENDRIKS, J. 1991. Een vitale en aantrekkelijke gemeente: model en methode van gemeenteopbouw. 2e druk. Kampen : Kok. 
HENDRIKS, J. 1992. Strategiese beplanning in die gemeente: die beginsels en praktyk van gemeentevernuwing. Wellington : Hugenote-uitgewers.

HENDRIKSEN, W. 1974. New Testament Commentary: Colossians \& Philemon. Edinburgh : Banner.

HEYNS, L.M. \& PIETERSE, H.J.C. 1990. Eerste treë in die Praktiese Teologie. Pretoria : Gnosis.

KRAEMER, H. 1958. A Theology of the Laity. London : Lutterworth.

KUYPER, A. 1909. Encyclopedie der Godgeleerdheid. Derde Deel. 2e druk. Kampen : Kok.

LADD, G.E., 1975. A Theology of the New Testament. 2nd print. Grand Rapids : Eerdmans.

LADD, G.E. 1976. The Presence of the Future: the Eschatology of Biblical Realism. 2nd printing. Grand Rapids : Eerdmans.

LOUW, D.J. 1980. Die stad in die mens: oor kerk-wees vandag. Pretoria : NG Kerkboekhandel.

LOUW, D.J. 1985. Die opbou van die gemeente in 'n veranderende samelewing. (In Louw, D.J., red. Op die breuklyn: 'n feesbundel saamgestel ter herdenking van die 125 -jarige bestaan van die Teologiese Seminarium Stellenbosch. Kaapstad : NG Kerkuitgewers. p. 20-42.)

LOUW, J.P. \& NIDA, E.A. 1988. Greek-English Lexicon of the New Testament Based on Semantic Domains. Volume I: Introduction \& domains. New York : United Bible Societies.

MARTIN, R.P. 1975. Colossians: The Church's Lord and the Christian's Liberty. An Expository Commentary with a Present-day Application. Exeter : Paternoster.

MƯLLER, J.J. 1958. Die brief van die apostel Paulus aan die Kolossense. Stellenbosch : CSV.

NEL, M. 1982. Die opbou van die gemeente. Skrif en kerk, 3(1):42-47.

NEL, M. 1987. Teologiese perspektiewe op gemeentebou. 2e druk. Pretoria : NG Kerkboekhandel. (Universiteit Pretoria Teologiese Studies, nr. 2.)

NEL, M. 1988. Fases in gemeentebou. Pretoria : NG Kerkboekhandel. (Universiteit Pretoria Teologiese Studies, nr. 6.)

NEL, M. 1994. Gemeentebou. Halfway House : Orion.

NOORDEGRAAF, A. 1980. Gods bouwwerk: aspecten van het gemeente-zijn in bijbels-theologisch licht. 's-Gravenhage : Boekencentrum.

NOORDEGRAAF, A. 1990. Overwegingen rondom het thema gemeenteopbouw. Theologia Reformata, 33:123-145.

POP, F.J. 1987. Bijbelse woorden en hun geheim: verklaring van een aantal Bijbelse woorden. 's-Gravenhage : Boekencentrum. 


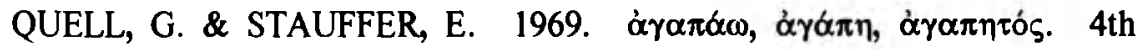
printing. (In Kittel, G., ed. Theological Dictionary of the New Testament. Volume I. Grand Rapids : Eerdmans. p. 21-55.)

RICHARDS, L.O. 1981. A New Face for the Church. Grand Rapids : Zondervan.

RIDDERBOS, H. 1955. Heilsgeschiedenis en Heilige Schrift van het Nieuwe Testament: het gezag van het Nieuwe Testament. Kampen : Kok.

RIDDERBOS, H. 1960. Commentaar op het Nieuwe Testament: Aan de Kolossenzen. Kampen : Kok.

RIDDERBOS, H. 1971. Paulus: ontwerp van zijn theologie. 2e druk. Kampen : Kok.

ROBERTS, J.H. 1984. Die kerk by Paulus. (In Du Toit, A.B., red. Handleiding by die Nuwe Testament. Band V. Die Pauliniese Briewe: Inleiding en teologie. Pretoria : N.G. Kerkboekhandel. p. 282-319.)

SCHWEIZER, E. 1982. The Letter to the Colossians: A Commentary. Minneapolis : Augsburg.

SCHWEIZER, E. \& BAUMGÄRTEL, F. 1971. $\sigma \hat{\omega} \mu \alpha-\sigma \dot{\sigma} \sigma \sigma \omega \mu \circ \varsigma$. (In Kittel, G., ed. Theological Dictionary of the New Testament. Volume VII. Grand Rapids : Eerdmans. p. 1024-1094.)

SMIT, A. 1995. Inleiding. (In Smit, A., red. Gemeente en bediening. Deel 4. Nuut gedink oor leierskap in gemeentes - die begeleiding van 'n Christelike geloofsgemeenskap. Kaapstad : Lux Verbi. p. 11-13.)

SPOELSTRA, B. 1976. Die diens van ouderling vandag. In die Skriflig, 10(37):41-48, Mrt.

SPOELSTRA, B. 1986. Het ons kerkwees in strukture gestol? In die Skriflig, 20(80):4-17, Des.

SPOELSTRA, B. 1989. Gereformeerde kerkreg en kerkregering: 'n handboek by die Kerkorde. Hammanskraal : HTS.

TE VELDE, M. 1989. Gereformeerde gemeenteopbouw: een eerste koersbepaling voor een nieuw theologisch vak. Bameveld : Vuurbaak. (Kamper Bijdragen, nr. XXX.)

TE VELDE, M. 1992a. Gemeenteopbouw 1: doelgericht en samehangend werken in de Christelijke gemeente. Bameveld : Vuurbaak.

TE VELDE, M. 1992b. Gemeenteopbouw 2. Bijbelse basisprincipes voor het functioneren van de Christelijke gemeente. Barneveld : Vuurbaak.

TRIMP, C. 1978. Inleiding in de amptelijke vakken. Kampen : Kok.

TRIMP, C. 1982. Zorgen voor de gemeente: het amptelijke werk van ouderlingen en diakenen toegelicht. Kampen : Van den Berg.

VAN DER WALT, J.J. 1976. Christus as die Hoof van die kerk en die presbiteriale kerkregering. Potchefstroom : Pro Rege. 
VAN ROON, A. 1984. Paulus. (In Baarlink, H., Duvekot, W.S. \& Geensee, A., reds. Vervulling en voleinding: de toekomstverwachting in het Nieuwe Testament. Kampen : Kok. p. 273-316.)

VELEMA, W.H. 1992. Een levende gemeente: met het oog op gemeenteopbouw. Kampen : Kok.

VENTER, C.J.H. 1988. 'n Nuwe-Testamentiese profiel van 'n gemeente wat homself opbou. (In Venter, C.J.H., red. God bou op deur sy Woord. Potchefstroom : PU vir CHO. p. 10-27.)

WETH, R. 1986. Vorwort. (In Weth, R., Hersg. Diskussion zur "Theologie des Gemeindeaufbaus". Neukirchen-Vluyn : Schriftenmissions-Verlag. p. 7-8.) 